NBER WORKING PAPER SERIES

THE EARNINGS OF UNDOCUMENTED IMMIGRANTS

George J. Borjas

Working Paper 23236

http://www.nber.org/papers/w23236

\author{
NATIONAL BUREAU OF ECONOMIC RESEARCH \\ 1050 Massachusetts Avenue \\ Cambridge, MA 02138 \\ March 2017
}

This research was supported by the U.S. Social Security Administration through grant \#RRC08098400-07 to the National Bureau of Economic Research as part of the SSA Retirement Research Consortium. The findings and conclusions expressed are solely those of the author(s) and do not represent the views of SSA, any agency of the Federal Government, or the NBER. I am particularly grateful to Mark Lopez and Jeffrey Passel of the Pew Research Center for their generosity in sharing data files. The views expressed herein are those of the author and do not necessarily reflect the views of the National Bureau of Economic Research.

NBER working papers are circulated for discussion and comment purposes. They have not been peer-reviewed or been subject to the review by the NBER Board of Directors that accompanies official NBER publications.

(C) 2017 by George J. Borjas. All rights reserved. Short sections of text, not to exceed two paragraphs, may be quoted without explicit permission provided that full credit, including () notice, is given to the source. 
The Earnings of Undocumented Immigrants

George J. Borjas

NBER Working Paper No. 23236

March 2017

JEL No. J31,J61,J68

\begin{abstract}
$\underline{\text { ABSTRACT }}$
Over 11 million undocumented persons reside in the United States, and there has been a heated debate over the impact of legislative or executive efforts to regularize the status of this population. This paper examines the determinants of earnings for undocumented workers. Using newly developed methods that impute undocumented status for foreign-born persons sampled in microdata surveys, the study documents a number of findings. First, the age-earnings profile of undocumented workers lies far below that of legal immigrants and of native workers, and is almost perfectly flat during the prime working years. Second, the unadjusted gap in the log hourly wage between undocumented workers and natives is very large (around 40 percent), but half of this gap disappears once the calculation adjusts for differences in observable socioeconomic characteristics, particularly educational attainment. Finally, the adjusted wage of undocumented workers rose rapidly in the past decade. As a result, there was a large decline in the wage penalty associated with undocumented status. The relatively small magnitude of the current wage penalty suggests that a regularization program may only have a modest impact on the wage of undocumented workers.
\end{abstract}

George J. Borjas

Harvard Kennedy School

79 JFK Street

Cambridge, MA 02138

and NBER

gborjas@harvard.edu 


\title{
The Earnings of Undocumented Immigrants
}

\author{
George J. Borjas*
}

\section{Introduction}

The Department of Homeland Security (DHS) estimates that over 11 million undocumented persons resided in the United States in January 2012. In the past few years, Congress considered (but failed to enact) a number of proposals that would regularize the status of the undocumented population and provide a "path to citizenship.” Similarly, President Obama issued executive orders that would grant some form of amnesty to about half of this population, but courts ruled that the executive branch may lack such authority.

Given the size of the undocumented population, any future change in the immigration status of this group is bound to have significant effects on the labor market and the broader economy. However, any evaluation that attempts to predict the economic impact of regularization immediately runs into a major roadblock. It is difficult to conduct such a calculation because we know little about the economic status of the 11 million undocumented persons already living in the United States.

The documentation of the economic status of this population is obviously hampered by the fact that no widely available microdata survey reports whether a particular foreign-born person is undocumented or not. In recent years, however, there has been progress in developing methods that attempt to impute the undocumented status of foreign-born persons at the individual level in microdata sets, such as the Current Population Surveys or the American

\footnotetext{
* This research was supported by the U.S. Social Security Administration through grant \#RRC08098400-07 to the National Bureau of Economic Research as part of the SSA Retirement Research Consortium. The findings and conclusions expressed are solely those of the author(s) and do not represent the views of SSA, any agency of the Federal Government, or the NBER. I am particularly grateful to Mark Lopez and Jeffrey Passel of the Pew Research Center for their generosity in sharing data files.
} 
Community Surveys. These attempts build on the framework first proposed by Warren and Passel (1987) that attempts to estimate the size of the undocumented population. The PasselWarren methodology, in fact, underlies the "official” estimates of this population as reported by DHS.

Jeffrey Passel (now at the Pew Research Center) and various colleagues have continued to improve and extend the initial methodology over the past two decades. As part of this work, they have constructed micro-level CPS files that contain a variable indicating if a foreign-born person is "likely authorized” or "likely unauthorized.” I was granted access to the 2012-2013 Annual Socioeconomic and Economic Supplements (ASEC) created by the Pew Research Center that contains the undocumented status identifier. After carefully examining the Pew methodology, I adapted and extended their approach so that I could create an undocumented status identifier in other micro data files, including all the ASEC files where foreign-born status is reported (i.e., all the ASEC files beginning in 1994) and the American Community Surveys (ACS). This extension of the Pew approach yields a time series of individual-level data that allows us to document and examine the determinants of key characteristics of the undocumented population.

Borjas (2018) began such an analysis by studying differences in labor supply behavior among undocumented immigrants, legal immigrants, and natives. The differences in work propensities were striking. Undocumented men had much larger labor force participation and employment rates than other groups in the population; the gap widened substantially over the past two decades; and the labor supply elasticity of undocumented men was close to zero, suggesting that their labor supply is very inelastic. In contrast, undocumented women had much lower participation and employment rates than other groups in the population. 
Building on this earlier work, this paper extends the analysis to an examination of the wage differences that exist among the various groups. The analysis of both the CPS and the ACS yields a number of potentially important findings:

1. The (cross-section) age-earnings profiles of undocumented workers lies far below that of legal immigrants and of native workers. Moreover, the (cross-section) age-earnings profile of undocumented workers is almost perfectly flat during much of the prime working years.

2. Although the unadjusted gap in the log hourly wage between undocumented workers and natives is large (around 40 percent for both men and women), half of the gap disappears after adjusting for differences in observable socioeconomic characteristics. The wage gap between observationally equivalent undocumented workers and natives (adjusted for age, education, and state of residence) is less than 20 percent for both men and women.

3. The adjusted wage of undocumented workers rose rapidly in the past decade, relative to that of both native workers and legal immigrants.

4. The rise in the adjusted wage of undocumented workers implies that the wage penalty to undocumented status fell dramatically in the past few years. This wage penalty, defined as the wage gap between observationally equivalent undocumented and legal immigrants, was about 10 percent in 2005, but fell to less than 4 percent by 2014. The small magnitude of the current wage penalty suggests that the enactment of a regularization program may only have modest effects on the wage of undocumented workers.

5. The higher employment rates of undocumented men imply that the total earnings gap (the gap that includes both the difference in the wage rate and differences in labor supply) is far smaller than suggested by the gap in the hourly wage rate. In contrast, the lower employment 
rates of undocumented women imply that the total earnings gap is far larger than suggested by the gap in the hourly wage rate.

This diverse set of findings provides a foundation upon which any eventual impact analysis of the various regularization proposals can be based. It is important to acknowledge at the outset, however, that the robustness of the evidence depends on the validity of the procedure used to impute undocumented status at the micro level.

\section{Imputing Undocumented Status in Microdata Files}

Warren and Passel (1987) introduced the "residual” methodology used by the DHS to calculate the size of the undocumented population. The first step involves estimating how many legal immigrants should reside in the United States at a point in time. Over the years, immigration officials have tracked the number of legal immigrants admitted to the country (i.e., the number of "green cards" granted each year). We also know how many foreign-born persons live in the United States temporarily (e.g., foreign students, business visitors, diplomats, etc.). These data enable us to apply mortality tables to the cumulative count of green cards and predict how many legal immigrants should be residing in the United States at any given point in time.

At the same time, many government surveys, such as the decadal census, enumerate or sample the U.S. population and specifically ask where each person was born. These surveys provide estimates of how many foreign-born people are actually living in the country. In rough terms, the difference between the number of foreign-born persons who are actually living in the 
United States and the number of legal immigrants who should be living in the United States is the Warren-Passel (and now “official” DHS) estimate of the number of undocumented persons. ${ }^{1}$ Jeffrey Passel has continued to work on the identification and enumeration of undocumented immigrants over the past two decades. As a result of these efforts, Passell (and colleagues at the Pew Research Center) have developed a comparable methodology that attempts to identify the undocumented immigrants at the individual level in survey data. This important extension of the Warren-Passel methodology relies on the same residual approach that was initially used to calculate the size of the undocumented population.

Passel and Cohn (2014) describe the methodology used to add an undocumented status identifier to the Annual Social and Economic Supplement (ASEC) files of the CPS. In rough terms, the methodology identifies the foreign-born persons in the sample who are likely to be legal, and then classifies the residual group as likely to be undocumented. In particular:

All immigrants entering the U.S. before 1980 are assumed to be legal immigrants. Then, the CPS data are corrected for known over-reporting of naturalized citizenship on the part of recently arrived immigrants... and all remaining naturalized citizens from countries other than Mexico and those in Central America are assigned as legal. Persons entering the U.S. as refugees are identified on the basis of country of birth and year of immigration...Then, individuals holding certain kinds of temporary visas (including students, diplomats and "hightech guest workers”) are...assigned a specific legal temporary migration status...Finally, some individuals are assigned as legal immigrants because they are in certain occupations (e.g., police officer, lawyer, military occupation, federal job) that require legal status or because they are receiving public benefits (e.g.,

\footnotetext{
1 Note that government surveys, including the decadal census, miss many people. Some of the people missed are undocumented immigrants who wish to avoid detection. To calculate an estimate of the size of the undocumented population, the Warren-Passel methodology must make an assumption about the undercount rate. The DHS assumes that the undercount for undocumented persons is 10 percent (Baker and Rytina, 2013, p. 6).
} 
welfare or food stamps) that are limited to legal immigrants. As result of these steps, the foreign-born population is divided between individuals with "definitely legal" status... and a group of "potentially unauthorized" migrants...[There is also] a check to ensure that the legal statuses of family members are consistent; for example, all family members entering the country at the same time are assumed to have the same legal status (Passel and Cohn, p. 23).

Passel and Cohn (2014) observe that this approach leads to "too many" undocumented immigrants. They then apply a filter to ensure that the counts from the microdata agree with the reported DHS numbers: "To have a result consistent with the residual estimate of legal and unauthorized immigrants, probabilistic methods are employed to assign legal or unauthorized status to these potentially unauthorized individuals." The CPS sample is then reweighted so that the aggregate count of undocumented immigrants matches as closely as possible the DHS estimates.

I was granted access to the 2012-2013 ASEC files that are maintained by the Pew Research Center. Figure 1 illustrates the percent of the U.S. population by age that is imputed to be undocumented in the Pew ASEC files. The DHS official counts imply that 3.7 percent of the U.S. population is undocumented. The Pew files suggest that a very high fraction (almost 10 percent) of persons in their early 30s are undocumented.

After being granted access to the Pew ASEC files (but not to the underlying code), I examined the demographic characteristics of those persons identified as undocumented immigrants in the pooled 2012-2013 cross-sections. Despite the inherent complexity in the residual method of identifying the subsample of the likely undocumented, it turns out that only a relatively small number of variables "matter" in the mechanical process of creating the undocumented identifier. This fact suggests that it may be possible to reverse engineer the 
method to create a comparable undocumented identifier in all of the ASEC files since 1994 as well as in other data sets.

The algorithm I use to create a comparable undocumented status identifier in all the relevant ASEC files is as follows. A foreign-born person is classified as a legal immigrant if any of the following conditions hold:

a. that person arrived before 1980;

b. that person is a citizen;

c. that person receives Social Security benefits, SSI, Medicaid, Medicare, or Military Insurance;

d. that person is a veteran, is currently in the Armed Forces;

e. that person works in the government sector;

f. that person resides in public housing or receives rental subsidies, or that person is a spouse of someone who resides in public housing or receives rental subsidies;

g. that person was born in Cuba (as practically all Cuban immigrants were granted refugee status);

h. that person's occupation requires some form of licensing (such as physicians, registered nurses, air traffic controllers, and lawyers);

i. that person's spouse is a legal immigrant or citizen.

The residual group of all other foreign-born persons is then classified as undocumented. Unlike the Pew methodology, my reconstruction of the undocumented identifier does not involve any kind of probabilistic sampling to account for the "excess" number of undocumented immigrants that this method yields, nor does it reweight the data to ensure that the total counts of the undocumented match the DHS official counts.

As Figure 1 shows, the predicted fraction of undocumented immigrants in the population at any particular age is essentially the same regardless of whether I use the Pew files or the 
reconstructed CPS files. This similarity suggests that it may be possible to extend the exercise to create an undocumented status identifier for all foreign-born persons sampled by the CPS throughout the entire 1994-2014 period, as well as extend the methodology to other microdata files, such as the American Community Surveys (ACS), which contain much larger samples of the population.

I applied the algorithm to the pooled 2011-2012 ACS files, and Figure 1 also illustrates the age profile in the fraction of the population that is undocumented. ${ }^{2}$ It is evident that the fraction of persons who are imputed to be undocumented closely tracks the fraction predicted by the Pew CPS files, suggesting that the ACS can perhaps be fruitfully used to study differences in the wage structure among the various groups. It is crucial to emphasize yet again, however, that the validity of the evidence obviously depends on the accuracy of the process used to impute undocumented status in the original Pew algorithm. In the absence of administrative data on the characteristics of the undocumented population, it is not possible to quantify the direction and magnitude of any potential bias.

Table 1 reports summary statistics for the male sample of working natives, legal immigrants, and undocumented persons in each of the three data extracts (i.e., the Pew CPS files, my reconstruction of the CPS files, and the ACS). The sample is restricted to men aged 25-64 who are not enrolled in school, are not self-employed, and report positive wage and salary income, positive weeks worked, and positive usual hours worked weekly.

There is a lot of similarity in the characteristics of the three groups across the data extracts. The fraction of the population that is undocumented is 6.9 percent in the Pew CPS, 7.4 percent in the reconstructed CPS, and 6.8 percent in the ACS). The average age of

\footnotetext{
2 The only difference in the algorithms applied to the CPS and ACS data arises because the ACS does not identify whether a particular household is living in public housing or is receiving subsidized rents.
} 
undocumented immigrants is practically identical in all three files (at 37.2 years). Similarly, 45.5 of undocumented persons in the Pew files are high school dropouts, as compared to 42.2 percent in the reconstructed ASEC files, and 43.7 percent in the ACS files.

I also calculated the hourly wage rate for each worker in the sample (defined as wage and salary income divided by the product of weeks worked in the past year and usual hours worked weekly). Table 1 shows that the log wage gap between undocumented workers and natives is similar across the data sets. The wage disadvantage of undocumented workers is $-0.455 \log$ points in the Pew CPS; - 0.452 log points in the reconstructed CPS; and -0.404 in the ACS data.

\section{Wage Differences across Groups}

I begin by examining the determinants of the differences in the log hourly wage rate across the various groups. Initially, I use the pooled 2012-2013 ASEC files created by Passel and colleagues at the Pew Research Center and restricted to workers aged 21-64, as well as the reconstructed CPS files and ACS files described in the previous sections that cover the same time period. ${ }^{3}$ Throughout this section, I will pool the two cross-sections and treat them as a single data set.

It is useful to begin by simply illustrating the differences in the age-earnings profiles across the three groups implied by the raw data. Figure 2 shows the age-earnings profiles in the sample of working men, while Figure 3 shows the corresponding profiles in the sample of working women. Figure 4 summarizes by contrasting the age-earnings profiles of undocumented

\footnotetext{
3 Because the CPS reports earnings in the previous calendar years, the analysis uses the comparable 2011 and 2012 cross-sections of the ACS.
} 
workers across the three data extracts. The figures suggest a number of interesting findings that are common across the different data sets examined.

First, and most important, the (cross-section) age-earnings profiles of undocumented workers lie far below those of the other two groups and are relatively flat. At the age of 25, for example, the hourly wage of undocumented workers in the ACS is 0.23 log points below that of natives and 0.17 log points below that of legal immigrants. By age 45 , the wage gap between natives and undocumented immigrants rose to 0.51 log points, while the wage gap between legal immigrants and undocumented workers rose to 0.39 log points.

Second, note that the pattern of lower and flatter age-earnings profiles for undocumented workers is observed both among working men and among working women. In each case, the hourly wage rate of undocumented workers reveals remarkably little growth during the prime working years between the ages of 30 and 50 .

Finally, as Figure 4 shows, the three alternative data sets show very similar age-earnings profiles for undocumented workers. In other words, the application of the reverse-engineered Pew algorithm to alternative data sets provides a consistent picture of earnings over the life cycle for undocumented workers. It is worth noting that the much larger samples available in the ACS smooth out the year-to-year noise.

It is important to emphasize that it is difficult to interpret the cross-section age-earnings profiles of both legal, and particularly, undocumented workers as measuring some type of wage evolution over the life cycle. It is well known (Borjas, 1985) that cross-section age-earnings profiles of immigrants are affected by both assimilation effects, the wage growth that occurs as a particular immigrant gets older, and by cohort effects, the differences in earnings potential across waves of immigrants that entered the United States at different times. The wage evolution of the 
undocumented sample is also affected by the fact that some of the undocumented will be able to "filter themselves" out and obtain green cards as they age, joining the legal sample, and by the fact that changes in the legal infrastructure regulating illegal immigration (such as nonenforcement of existing laws or enactment of new penalties) might affect the flow of undocumented workers in and out of the country over time. Some of these issues are discussed in greater detail in subsequent sections.

To document the determinants of the large wage disadvantage experienced by undocumented workers, particularly when compared to native workers, I estimated the following regression model:

$$
\log w_{i}=\delta_{t}+\theta X_{i}+\beta_{1} L_{i}+\beta_{2} U_{i}+\varepsilon_{i},
$$

where $w_{i}$ is the hourly wage rate of worker $i ; \delta_{t}$ is a dummy variable indicating if the observation is drawn from the 2012 or 2013 cross-section in the CPS (or the 2011 or 2012 cross-section in the ACS); $X_{i}$ is a vector of socioeconomic characteristics described below; $L_{i}$ is a dummy variable indicating if the worker is a legal immigrant; $U_{i}$ is a dummy variable indicating if the worker is an undocumented immigrant; and the excluded group indicates if worker $i$ is nativeborn. The coefficients $\beta_{1}$ and $\beta_{2}$ measure the log wage gaps between the two foreign-born groups and the native-born workforce. The regressions are estimated separately for men and women.

The first two columns of Table 2 report the regression coefficients for men, while the last two columns report the respective coefficients for women. Each panel in the table reports the estimated coefficients in each of the three alternative data files. As row 1 of each panel shows, the unadjusted log wage gap between undocumented immigrants and natives is -0.46 in the Pew 
files; -0.45 in the reconstructed CPS, and -0.40 in the ACS. It is evident that much of the wage gap between undocumented immigrants and natives can be explained by differences in educational attainment. The education- and age-adjusted wage disadvantage of undocumented men reported in row 3 falls to -0.18 in the Pew CPS, -0.19 in the reconstructed CPS, and -0.15 in the ACS. Even after adjusting for the fact that undocumented immigrants tend to cluster in a small number of states, the wage disadvantage of undocumented workers relative to natives remains sizable, hovering around -0.20 log points in the various data extracts.

The regression coefficients also imply that even holding age, education, and state of residence constant, there is a wage gap between legal immigrants and undocumented workers. Depending on the data set examined, this "wage penalty" to undocumented status ranges between 10 and 12 percent. The determinants and trends in this wage penalty will be discussed in much greater detail in the next section.

The last two columns of Table 2 report the respective wage gaps in the female workforce. It is again evident that undocumented workers earn about 20 percent less than natives, after controlling for the various socioeconomic characteristics, and that there is a wage penalty to undocumented status, again ranging around 10 to 12 percent.

Note that the ACS provides similar estimates of the wage gaps as the CPS and that it provides a much larger sample for examining the earnings of undocumented workers. As a result, it may be fruitful to use the ACS to document trends in the wage of undocumented workers over the 2001-2014 period. This period witnessed both a rapid increase in the size of the undocumented population (from 8.5 million to over 11 million between 2000 and 2006 according to the DHS), as well as the stabilization of the size of the undocumented population since 2006. 
I estimated the regression model in equation (1) for each separate year in the ACS between 2001 and 2014 (separately for men and women). The two panels of Figure 5 illustrate the key trend in the wage gaps (i.e., the coefficients $\beta_{1}$ and $\beta_{2}$ ) between the two types of immigrants and the baseline native workforce. The figure illustrates the trend in both the unadjusted wage gap (as in row 1 of Table 2), and the wage gap adjusted for age, education, and state of residence differences (as in row 4 of the table).

The relative wage of legal immigrant men has shown little trend in the past 15 years. Note further that the adjusted wage gap for legal immigrants is smaller than the unadjusted wage gap, implying that part of the relative success of legal immigrants arises because they have slightly more valuable observable characteristics. The adjusted wage gap for legal immigrants has hovered at around $-0.1 \log$ points over much of the past 15 years.

In contrast, the adjusted wage gap for undocumented immigrants is far above the unadjusted wage, implying that much of the poor performance of undocumented immigrants arises because they lack observable socioeconomic characteristics that are valued in the labor market. Equally important, the adjusted relative wage of undocumented immigrants began to increase around 2008. In 2007, the adjusted wage gap between undocumented men and natives was $-0.25 \log$ points. By 2014, this statistic had shrunk to -0.16 log points. In other words, there was a decline in the wage disadvantage of undocumented men of about 10 percentage points in a very short time period. it is also evident that there was also an improvement in the earnings of undocumented women, although the improvement was smaller for women (about 7 percentage points). 
The relatively constant adjusted wage of legal workers and the increase in the wage of undocumented workers suggest that there was an important shrinkage in the wage penalty arising because of undocumented status.

\section{Trends in the Wage Penalty}

I define the wage penalty to undocumented status as the difference between what the average legal worker earns relative to what an observationally equivalent undocumented immigrant earns. This wage penalty can be easily calculated by conducting an Oaxaca decomposition of the wage difference between legal and undocumented immigrants. In particular, I estimate the regression models (separately for each gender):

$$
\begin{array}{ll}
\text { Legal Immigrant Earnings Function: } & \log w_{\mathrm{L}}=\beta_{\mathrm{L}} h_{\mathrm{L}}+\varepsilon_{\mathrm{L}}, \\
\text { Undocumented Immigrant Earnings Function: } & \log w_{\mathrm{U}}=\beta_{\mathrm{U}} h_{\mathrm{U}}+\varepsilon_{\mathrm{U}},
\end{array}
$$

where $w_{j}$ gives the hourly wage of group $j(j=L$ for legal immigrants and $U$ for undocumented immigrants); and $h_{j}$ gives a vector of socioeconomic characteristics that affect earnings (including a constant term). The coefficients in the vector $\beta_{L}$ give the payoff to these socioeconomic characteristics for legal immigrants, while the respective coefficients in the vector $\beta_{U}$ gives the payoff for undocumented immigrants.

The wage penalty associated with being an undocumented worker is then given by:

$$
P=\left(\beta_{L}-\beta_{U}\right) \bar{h}_{U},
$$


where $\bar{h}_{U}$ gives the mean value of the characteristics for undocumented immigrants. It is obvious from equation (3) that the wage penalty will be a positive number as long as the labor market values the socioeconomic characteristics of a legal immigrant by more than it values the respective characteristics of an undocumented worker.

I initially estimate the wage penalty in the pooled 2012-2013 CPS cross-sections (and the comparable 2011-2012 ACS cross-sections). The socioeconomic characteristics of the various groups were indeed valued at very different rates in the U.S. labor market at that time (i.e., $\beta_{L} \neq$ $\beta_{U}$ ). To illustrate, Table 3 reports the differences associated with a particularly important socioeconomic characteristic, years of educational attainment. It is evident that the rate of return to schooling (i.e., shorthand for the coefficient of years of schooling in the log wage regression) is highest for native workers, and lowest for undocumented immigrants. Among men in the ACS, for example, the rate of return to schooling is 0.112 for native workers, 0.079 for legal immigrants, and 0.061 for undocumented immigrants.

Table 4 reports the wage penalty using alternative specifications of the vector of socioeconomic characteristics, $h$. The wage penalty to undocumented status is obviously best identified when the exercise adjusts for as many of these observed characteristics as possible. The vector $h$, therefore, includes age, educational attainment, years since migration, and state of residence. In the larger ACS sample, the regression also includes country of birth. It is notable that the wage penalty to undocumented status was relatively small circa 2012-2013, ranging between 5 and 8 percent for men, and 3 to 11 percent for women.

I also used the Oaxaca decomposition to calculate the wage penalty (using the full specification that includes country of birth) in each year of the ACS. Figure 6 illustrates the trend 
in the wage penalty for both men and women. The figure reveals a very interesting trend: The penalty was relatively constant until about 2007, at which point the wage penalty to undocumented status began to shrink (i.e., the wage penalty became less negative). In 2005, for example, the wage penalty for men was 9.1 percent; by 2010, the wage penalty stood at 5.7 percent; and by 2014, the wage penalty had fallen to 3.4 percent. The trends illustrated in Figure 6 have an obvious (and potentially important) implication: The wage impact of any widespread regularization of undocumented status may have only a minor effect on the average wage of undocumented workers currently residing in the United States. ${ }^{4}$

It is of interest to compare this wage penalty estimated using the imputed undocumented identifier in microdata files to existing estimates of how much legalization raises the wage of undocumented workers. Almost all existing estimates of this wage penalty come from studies that examine what happened to the earnings of the persons who received amnesty in 1986 as part of the Immigration Reform and Control Act (IRCA). Nearly 3 million illegal immigrants received amnesty at the time, and contemporaneous surveys tracked those immigrants as they received their legal working papers (Kossoudji and Cobb-Clark, 2002; and Kaushal. 2006). Their wage rose by at most 6 percent between 1989 and 1992 . The estimates of the wage penalty implied by the ACS around 2001 (the earliest year available), are somewhat higher (around 9 percent).

\footnotetext{
4 The comparable trend estimated in the reconstructed CPS is noisier, but also suggests a drop in the wage penalty after 2010. The difference between the trends calculated in the two data sets may arise for several reasons. First, there are well-known differences in the evolution of wages as measured by the CPS and the ACS. Second, the smaller CPS sample likely generates more random noise. And, finally, the value of the years-since-migration variable for newly arrived immigrants is not fully consistent across CPS cross-sections, contaminating the predicted wages. The decline in the CPS estimate of the wage penalty is more consistent with the ACS trend when that variable is excluded from the CPS regressions.
} 
It is difficult to identify precisely which factor is driving the observed decline in the wage penalty to undocumented status. One stumbling block is that the composition of the undocumented population has changed in unknown ways during this period. As noted earlier, the estimated number of undocumented immigrants rose sharply between 2000 and 2006, but has held steady since then. The constant number of undocumented persons, however, does not imply that the flow of undocumented immigrants stopped altogether in 2006. After all, some of the undocumented persons in the United States in 2006 may have left the country and many may have been able to adjust their immigration status and obtain a green card. These "exits" from the undocumented population were then replaced by a similarly sized flow of new undocumented immigrants. In short, we simply lack the requisite information that would enable us to precisely net out how much of the decline in the wage penalty to undocumented status can be accounted for by changes in the sample composition of the relevant populations over the past decade.

A number of sensitivity exercises can be conducted, however, that help to document that the sizable decline in the wage penalty was a widespread phenomenon across the U.S. labor market. For example, one can examine what happened to the entry wage disadvantage of new undocumented immigrants over the past 15 years. The top panel of Figure 7 re-estimates the wage penalty of undocumented immigrants by focusing on the sample of workers who have been in the United States exactly one year at the time of the ACS enumeration. ${ }^{5}$ It is evident that the wage penalty associated with undocumented status for the brand new immigrants also shrank substantially in the post-2008 period.

\footnotetext{
5 The wage penalty documented in Figure 7 adopts a simpler empirical strategy to ensure that small sample sizes do not create a lot of noise in the calculations. Rather than pursuing the Oaxaca decomposition strategy that allows all regression coefficients to differ between legal and undocumented immigrants, the
} 
It may seem easy to dismiss the trend in the wage penalty for the cohort of new immigrants by arguing that perhaps there are trends in unobservable characteristics that changed fundamentally after 2008, leading to a higher relative level of economic performance for the new undocumented immigrants that arrived in recent years. This hypothesis, however, cannot explain the trend. The bottom panel of Figure 7 shows the respective trend in the undocumented wage penalty accruing to immigrants who have been in the United States between 10 and 20 years as of the time of the survey, so that the migration decision was made many years prior to the changed legal environment that may have affected undocumented workers in the post-2008 period. The trend in the wage penalty paid by these older undocumented immigrants, particularly for men, is again quite similar; it shows a substantial decline in the post-2008 period.

An obvious hypothesis that may explain the decline in the wage penalty paid by all undocumented workers (whether brand new immigrants or long-time residents) is that there has been a favorable shift in the legal environment regarding undocumented immigration in the past decade, particularly during the years of the Obama administration. Unfortunately, the aggregate time-series in Figures 6 and 7 do not provide sufficient information that would help identify the impact of such economy-wide changes in the legal environment.

However, it may be possible to document that more local changes in the employment restrictions faced by undocumented workers affected the wage penalty. At the same time that the executive and legislative branches of the federal government were 
taking actions to regularize the status of many undocumented workers, some states took state-specific actions that made the economic status of undocumented workers less secure. In particular, several states enacted legislation further restricting and penalizing undocumented immigrants. The best known of these attempts was the 2010 legislation in Arizona that, among many things, "[required] law enforcement officers to determine immigration status during any lawful stop; [created] state crimes and penalties for failure to carry federally-issued alien registration documents; [made] it unlawful for an unauthorized alien to knowingly apply for or perform work in Arizona; and [permitted] an officer to make a warrantless arrest if the officer has probable cause to believe the person has committed any public offense that makes the person removable from the United States" (National Conference of State Legislatures, 2012).

One common provision in some of the state-level statutes was the requirement that employers use E-Verify to authenticate the legal status of new hires. As the Department of Homeland Security describes it: "E-Verify is an Internet-based system that compares information from an employee's Form I-9, Employment Eligibility Verification, to data from U.S. Department of Homeland Security and Social Security Administration records to confirm employment eligibility." 6 During the period under analysis, four states enacted legislation mandating that all private employers in those states use the E-Verify system to confirm the employment eligibility of new hires: Arizona beginning in 2008, Alabama in 2012, Mississippi in 2011, and South Carolina in 2010. ${ }^{7}$

\footnotetext{
${ }^{6}$ https://www.uscis.gov/e-verify/what-e-verify.

${ }^{7}$ NumbersUSA (2016); see also National Council of State Legislatures (2012).
} 
To determine whether such state-level legislation affected the wage penalty, I stacked all the 2001-2014 ACS cross-sections and estimated the following regression model in the pooled sample of legal and undocumented immigrants:

$$
\log w_{i s t}=\delta_{L t}+\delta_{L s}+\delta_{s t}+\theta h_{i s t}+\beta_{0} L_{i}+\beta_{1} V_{s t}+\gamma\left(L_{i} \times V_{s t}\right)+\varepsilon_{\text {ist }} \text {, }
$$

where $w_{i s t}$ is the hourly wage of worker $i$ in state $s$ at time $t$; $h$ represents a vector of socioeconomic characteristics; $L_{i}$ is a dummy variable indicating if the worker is a legal immigrant; and $V_{s t}$ is a dummy variable indicating if state $s$ mandated employers to use EVerify at time $t$. Note that the regression includes a vector of immigration status-year interaction fixed effects $\delta_{L t}$ designed to capture economy-wide changes in the wage penalty; a vector of immigration status-state interaction fixed effects $\delta_{L S}$ designed to capture permanent differences across states in the labor market for undocumented workers; and a vector of state-year interaction fixed effects $\delta_{s t}$ designed to capture statespecific trends in immigrant wages. The coefficient $\gamma$ then indicates if the state's requirement that employers use E-Verify affected the wage penalty experienced by undocumented immigrants. The regressions were estimated separately for men and women.

The first row of Table 5 reports the estimates of the triple-difference coefficient $\gamma$ in the ACS. The evidence shows that the coefficient is positive and significant when estimated in the sample of men, with a point estimate of 0.019 (and a standard error of 0.008). As reported earlier, the male wage penalty in the post- 2010 period hovered around 5 percent, so that the state-level restrictions on undocumented employment seemed to have 
increased the wage penalty by around 40 percent. In short, it seems as if the legal infrastructure surrounding undocumented status matters in the labor market. ${ }^{8}$ Note, however, that although the point estimate of the coefficient $\gamma$ is also positive for women, it is not significant. It is difficult to ascertain the reasons for the weak effect measured in the sample of working women, but the evidence may be indicating that the labor force participation of undocumented women may be particularly sensitive to state-specific restrictions, making it more difficult to identify how the wage penalty is affected by the legislation.

The next two rows of Table 5 re-estimate the ACS regressions in the sample of new immigrants (who have been in the United States at most one year) and older immigrants (tose who have been in the United States at least 10 years). The state-mandated implementation of E-Verify affects mainly new hires, so that it seems likely that newly arrived undocumented workers would be most affected by the legislation. The regression analysis confirms this expectation. The impact of the legislation on the wage penalty paid by new immigrant men is numerically very large (a point estimate of .144, with a standard error of .066), while the impact on earlier immigrants is not significantly different from zero.

Finally, to assess the robustness of the evidence, I estimated the regression in equation (3) using the reconstructed CPS data that contains the undocumented identifier. To make the CPS analysis comparable to that of the ACS, I restricted the CPS sample to the

\footnotetext{
8 Several studies examine labor market outcomes following adoption of the E-Verify program, including Amuedo-Dorantes and Bansak (2012), Bohn, Lofstrom, and Raphael (2015), and Orrenius and Zavodny (2015). The specific findings differ from study to study, but both Amuedo-Dorantes and OrreniusZavodny document a worsening in the wage of undocumented immigrants after the mandated adoption of the electronic system.
} 
2002-2015 surveys. The CPS evidence is, in fact, similar to that revealed by the ACS. The mandated use of E-Verify increased the wage penalty for undocumented men, but the point estimate (although positive) is not statistically significant for undocumented women.

In sum, the state-level evidence suggests that the legal environment faced by undocumented workers affects their labor market opportunities. The secular decline in the wage penalty paid by undocumented workers documented in Figure 6, however, partly reflects economy-wide changes in the set of opportunities available to the undocumented population. It would seem important to detail the specific aspects of the changed nationwide environment that reduced the average wage penalty so dramatically after 2008 .

\section{Labor Supply and Annual Earnings}

Up to this point, the analysis has examined the determinants of the hourly wage rate of undocumented workers relative to that of other workers. Borjas (2018) shows that there are sizable differences in labor supply between undocumented workers and both natives and legal immigrants. In particular, undocumented men are much more likely to work than other men, while undocumented women are far less likely to work than other women. In the early 2010s, for example, the typical undocumented man had a 92 percent probability of being employed at some point during the calendar year, as compared to 85 percent for legal immigrants, and 81 percent for native men. In contrast, the typical undocumented women had a 61 percent probability of working, as compared to 64 percent for legal immigrants, and 72 percent for native women. These sizable labor supply differences imply that the gaps in the hourly wage rate do not provide complete information on the differences in the economic well-being of the groups. 
I now extend the analysis to examine how group differences in labor supply affect the total earnings of persons in each of the groups. In particular, I shift the focus of attention to an analysis of the annual earnings of undocumented workers, legal immigrants, and natives, and estimate the difference in annual earnings both in the sample of working persons (as in the previous section) as well as in the sample of all persons, which include all the persons who did not work at all during a particular year.

Table 6 summarizes the key evidence resulting from this exercise. Specifically, the table reports regression coefficients from specifications similar to equation (1) estimated earlier, which pooled all three groups in the years 2012-2013 in the CPS sample extracts and the 2011-2012 ACS, and includes regressors indicating whether a particular person is a legal immigrant or an undocumented immigrant. The dependent variable is annual earnings (measured in thousands of dollars). Note that the dependent variable is not the log of annual earnings because the purpose of the exercise is to include in the analysis those persons who do not work and, therefore, have zero earnings. For simplicity, the table reports the coefficients resulting from the Pew CPS files and the much larger ACS files. It is evident that the two data extracts lead to roughly similar results, so that the discussion focuses exclusively on the results from the analysis that uses the larger ACS data.

Among working men, the adjusted annual earnings of undocumented workers in the early 2010s was about $\$ 9,900$ lower than that of native men in the ACS. Note, however, that if we include all persons in the regression, including the non-workers with zero annual earnings, the relative disadvantage of undocumented men narrows significantly, with the gap in annual earnings falling to only $\$ 4,100$. Among women, the opposite is true because undocumented women are less likely to work than other women. The adjusted gap in annual earnings among 
working women is $\$ 6,900$, but grows to $\$ 8,000$ if one includes the non-working women with zero earnings in the analysis.

One easy way to interpret the numerical importance of these effects is to restate the adjusted annual earnings gaps in percentage terms, which I construct by dividing the dollar gap implied by the regression coefficient by the mean annual earnings of natives. In addition, I estimated the regression model separately in each ACS cross-section.

Figure 8 illustrates the trend in these adjusted percent gaps for both men and women. Note that in 2015, the adjusted percent earnings gap for undocumented working men was around 15 percent, but falls to less than 10 percent when the calculation accounts for the disproportionately larger number of undocumented persons who are employed. The figures again document the improvement in the economic status of the male undocumented workforce after 2007. In 2007, the adjusted earnings gap (including non-workers) was around 16 percent. By 2014, this gap had shrunk to 8 percent.

\section{Summary}

The past decade has witnessed a series of attempts to create some type of "path to citizenship” for the over 11 million undocumented immigrants now residing in the United States. This paper uses newly developed algorithms that attempt to impute undocumented status for each person in microdata files, including the Current Population Surveys and the American Community Surveys, to examine the determinants of what is perhaps the key indicator of their economic well being, their earnings in the U.S. labor market.

The analysis yields a number of new insights into the determination of earnings for the large undocumented population: 
1. The age-earnings profiles of undocumented workers lies far below that of legal immigrants and of native workers. Moreover, the age-earnings profile of undocumented workers is almost perfectly flat during the prime working years.

2. The unadjusted gap in the log hourly wage between undocumented workers and natives is large (around 40 percent for both men and women). Half of this gap disappears once the calculation adjusts for differences in observable socioeconomic characteristics, including age, education, and state of residence.

3. The adjusted wage of undocumented workers rose rapidly in the past decade. As a result, there was a large decline in the wage penalty to undocumented status from about 10 percent in 2005 to less than 4 percent in 2014, where the wage penalty is defined as the wage gap between observationally equivalent undocumented and legal immigrants. The small magnitude of the current wage penalty suggests that the enactment of a regularization program may have only a modest effect on the wage of undocumented workers.

It is important to emphasize that the analysis reported in this paper represents but a first step in any evaluation of the various regularization proposals being discussed among policy makers. Much more information about the economic well being of the undocumented population needs to be documented before a full evaluation can be made. Similarly, it is crucial to continue to assess the validity of the imputation methods that must be used to determine a person's undocumented status in large survey data. 


\section{References}

Amuedo-Dorantes, Catalina, and Cynthia Bansak. 2012. "The Labor Market Impact of Mandated Employment Verification Systems,” American Economic Review Papers and Proceedings 102(3): 543-548.

Baker, Bryan, and Nancy Rytina. 2013. "Estimates of the Unauthorized Immigrant Population Residing in the United States: January 2012,” Washington, DC Department of Homeland Security, Office of Immigration Statistics.

Bohn, Sarah, Magnus Lofstrom, and Steven Raphael. 2015. "Do E-Verify Mandates Improve Labor Market Outcomes of Low-Skilled Native and Legal Immigrant Workers?” Southern Economic Journal 81(4), 960-979.

Borjas, George J. 1985. “Assimilation, Changes in Cohort Quality, and the Earnings of Immigrants,” Journal of Labor Economics 3(4): 463-489

Borjas, George J. 2018. “The Labor Supply of Undocumented Immigrants,” Labour Economics, forthcoming.

Hotchkiss, Julie L., and Fernando Rios-Avila. 2013. "Identifying Factors Behind the Decline in the U.S. Labor Force Participation Rate.” Business and Economic Research, Macrothink Institute 3 (1): 257-275.

Kossoudji, Sherrie A. and Deborah A. Cobb-Clark. 2002. "Coming Out of the Shadows: Learning about Legal Status and Wages from the Legalized Population.” Journal of Labor Economics 20(3): 598-628.

Kaushal, Neeraj. 2006. "Amnesty Programs and the Labor Market Outcomes of Undocumented Workers.” Journal of Human Resources 16(3): 631-647.

National Conference of State Legislatures. 2012. "State Omnibus Immigration Legislation and Legal Challenges,” August 27. Website: http://www.ncsl.org/research/immigration/omnibus-immigration-legislation.aspx.

National Conference of State Legislatures. 2012. “E-Verify,” August 27. Website: http://www.ncsl.org/research/immigration/everify-faq.aspx.

NumbersUSA. 2016. “Map of States with E-Verify Laws,” December 18. Website: https://www.numbersusa.com/resource-article/everify-state-map.

Orrenius, Pia M. and Madeline Zavodny, 2015. “The Impact of E-Verify Mandates on Labor Market Outcomes,” Southern Economic Journal 81(4): 947-959. 
Passel, Jeffrey S. and D’Vera Cohn. 2014. “Unauthorized Immigrant Totals Rise in 7 States, Fall in 14 States: Decline in Those From Mexico Fuels Most State Decreases.” Washington, DC: Pew Research Center.

Warren, Robert E. and Jeffrey S. Passel. 1987. “A Count of the Uncountable: Estimates of Undocumented Aliens Counted in the 1980 United States Census.” Demography 24(3): 375-393. 
Figure 1. Percent of population that is undocumented, by age (Pooled 2012-2013 CPS-ASEC files, pooled 2011-2012 ACS)

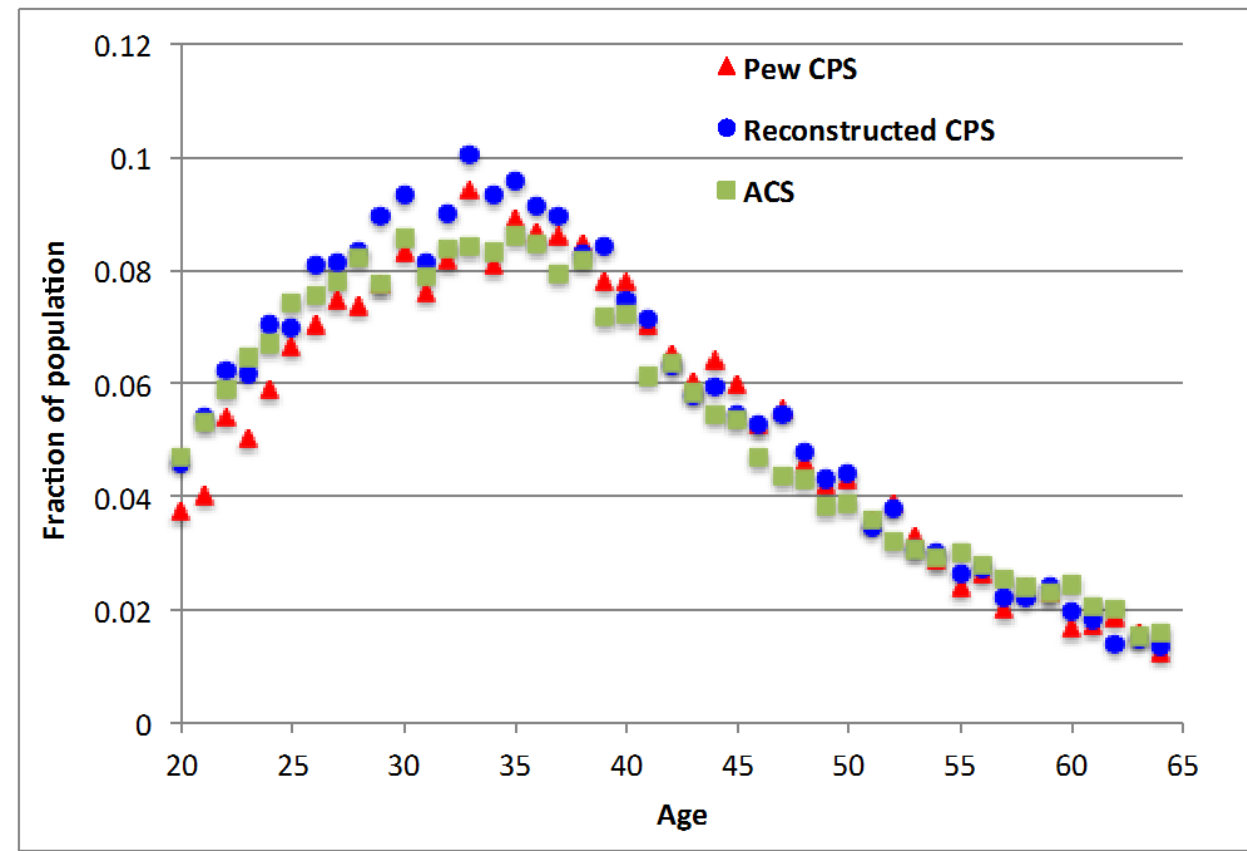

Notes: The figure calculates the percent of the population (at a particular age) that is foreign-born and is classified as undocumented using either the "likely unauthorized" status indicator created by Jeffrey Passel and colleagues at the Pew Research Center or my reconstruction of the undocumented status indicator in the CPS or the ACS (see text for details). 
Figure 2. Age-earnings profiles of working men, 2012-2013

\section{A. Pew CPS}

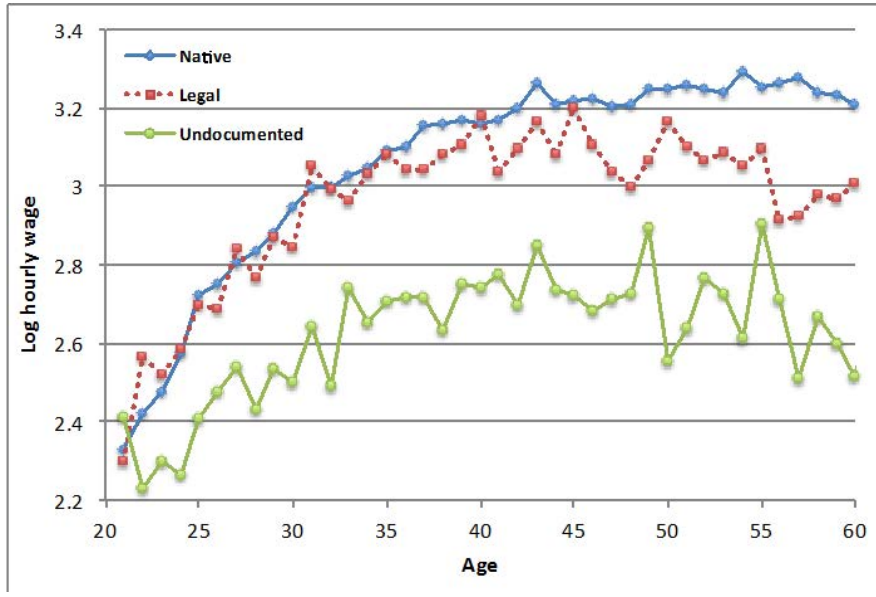

\section{B. Reconstructed CPS}

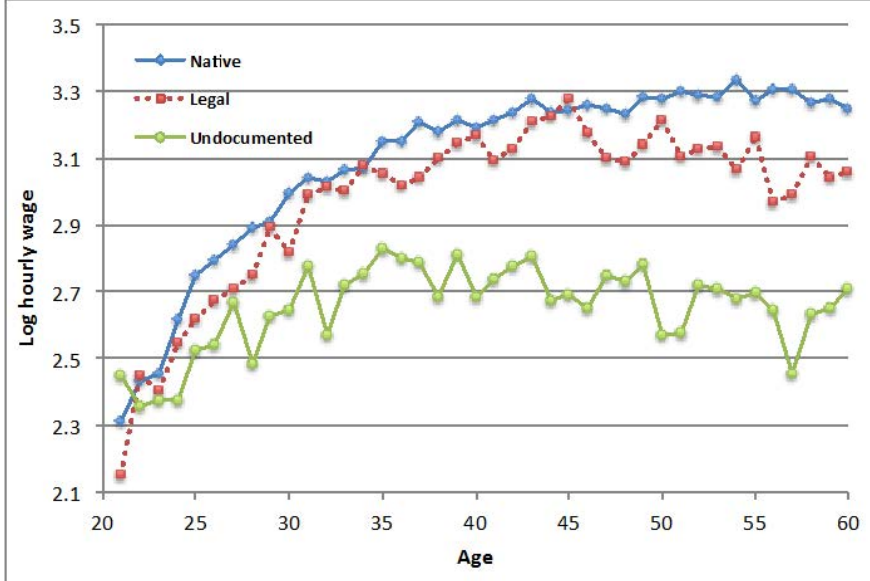

C. ACS

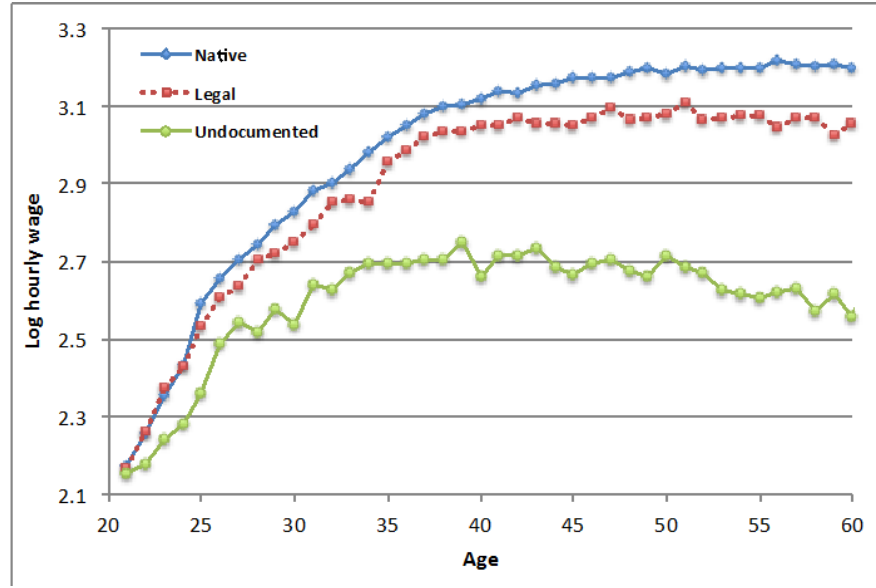

Notes: The age-earnings profiles report the average log hourly wage of workers in each of the nativity groups at each age. 
Figure 3. Age-earnings profiles of working women, 2012-2013

\section{A. Pew CPS}

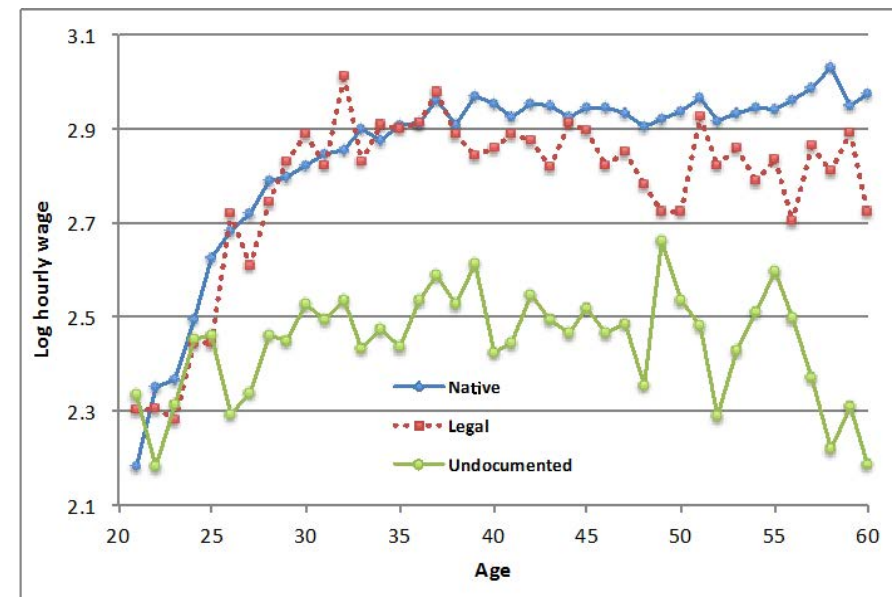

\section{B. Reconstructed CPS}

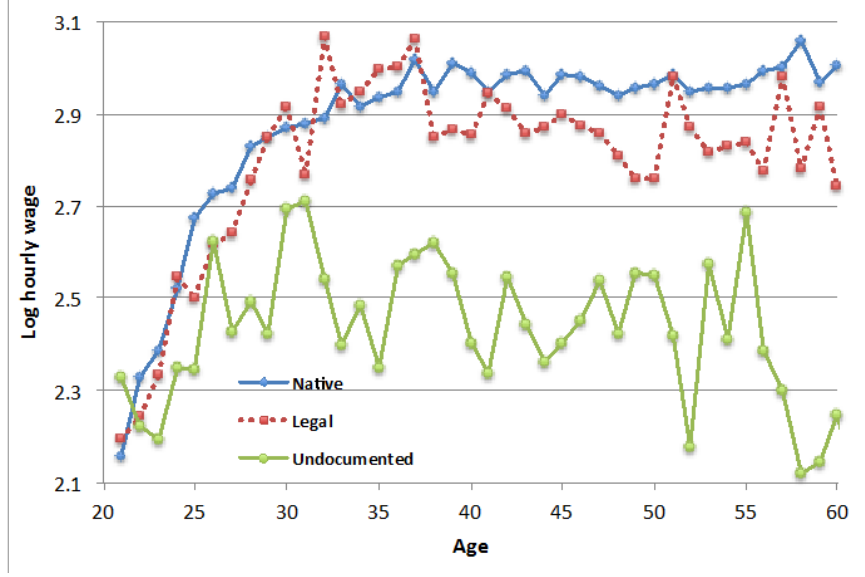

\section{ACS}

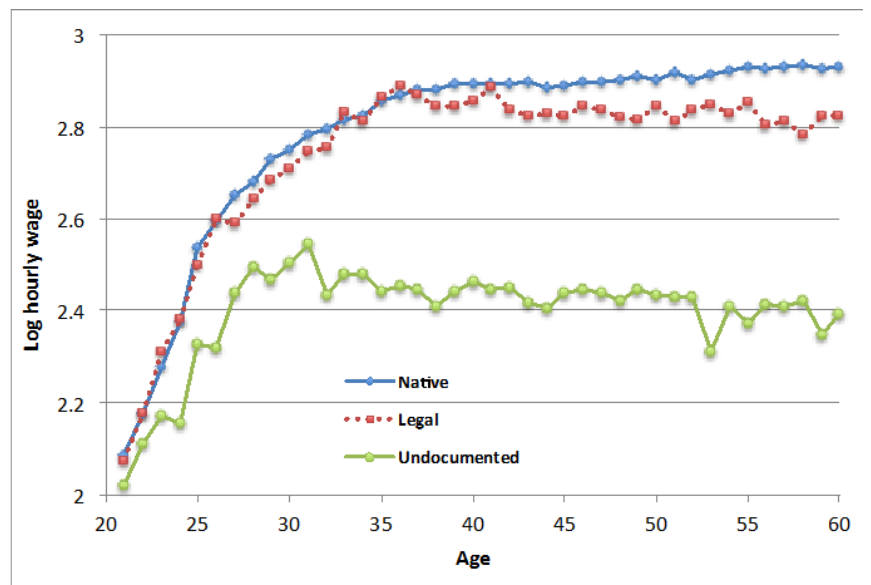

Notes: The age-earnings profiles report the average log hourly wage of workers in each of the nativity groups at each age. 
Figure 4. Age-earnings profiles of undocumented workers across data sets

A. Men

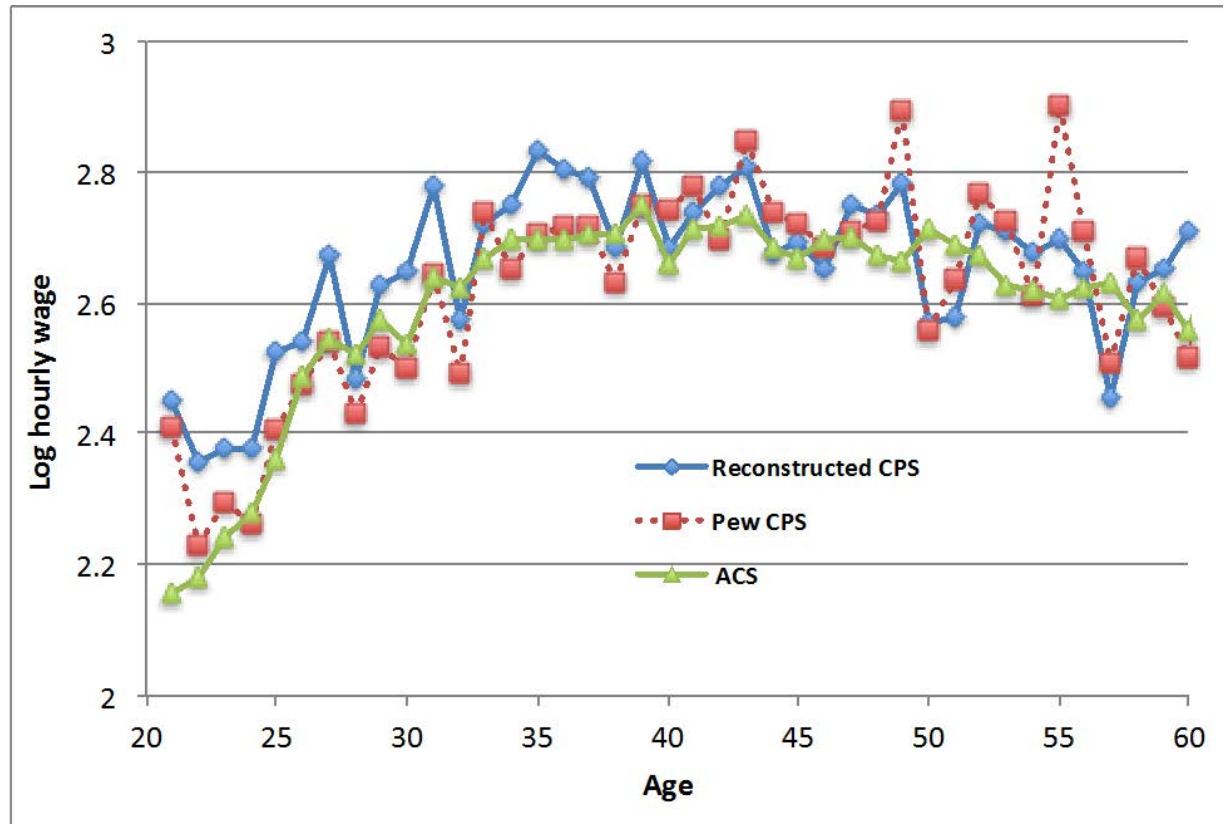

\section{B. Women}

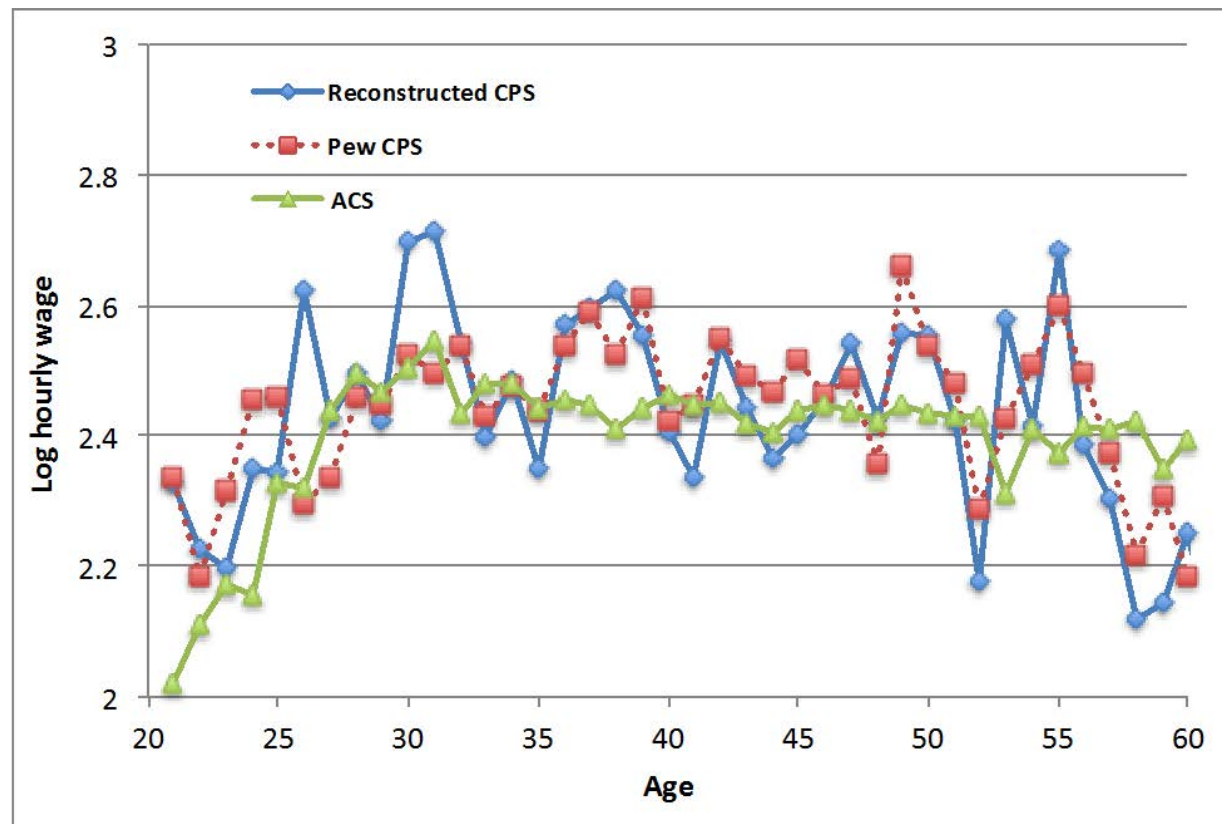

Notes: The age-earnings profiles report the average log hourly wage of undocumented workers at each age. 


\section{Figure 5. Trends in log hourly wage of legal and undocumented immigrants, relative to natives, ACS}

\section{A. Men}

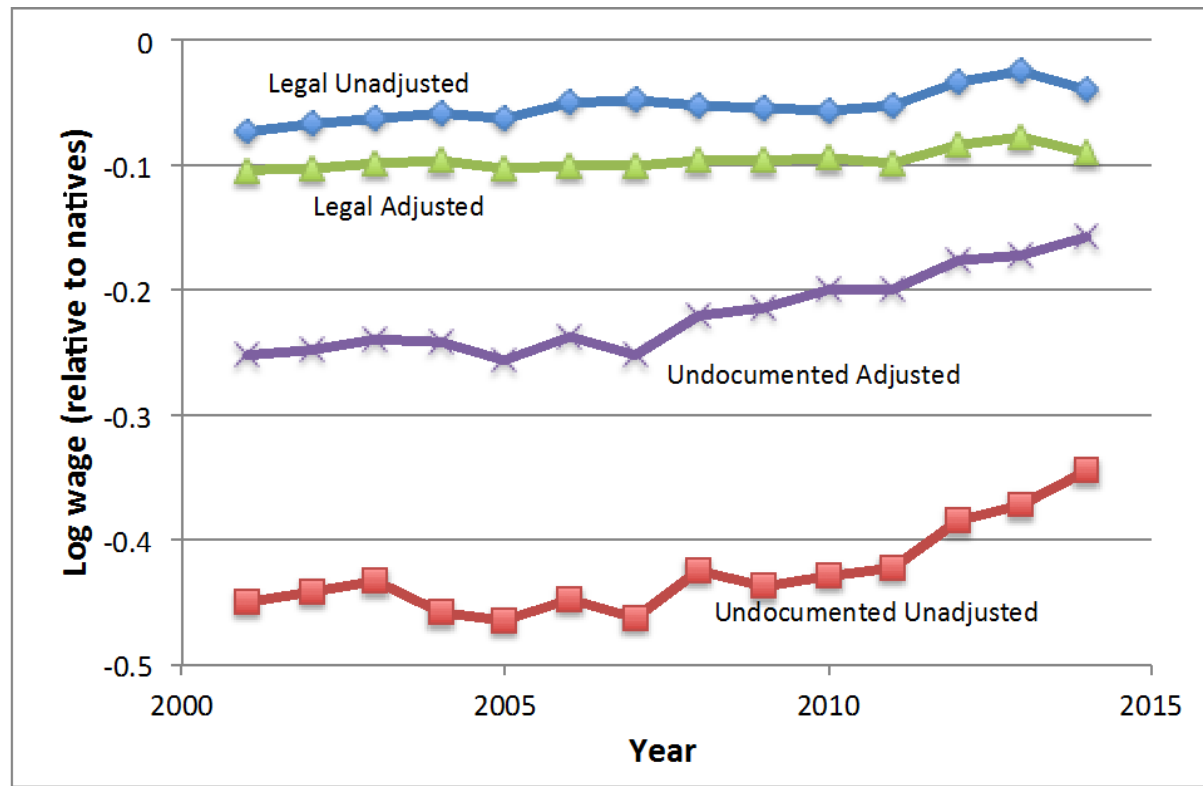

\section{B. Women}

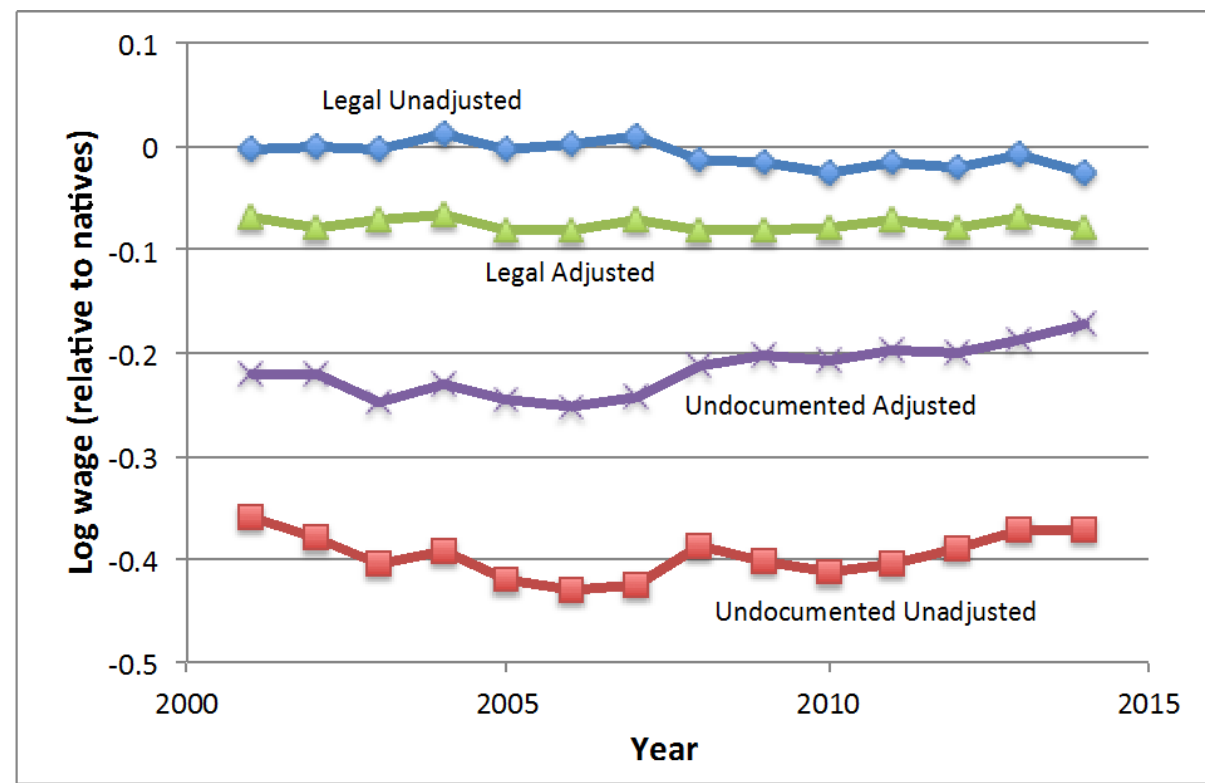

Notes: The figures illustrate the trend in the regression coefficient of dummy variables indicating whether a person is a legal immigrant or an undocumented immigrant, and the dependent variable in the regression is the log hourly wage rate. The unadjusted coefficient comes from a regression that does not include any additional regressors; the adjusted coefficient comes from a regression that controls for age, educational attainment, and state of residence. 
Figure 6. Trend in the wage penalty to undocumented workers, 2001-2014

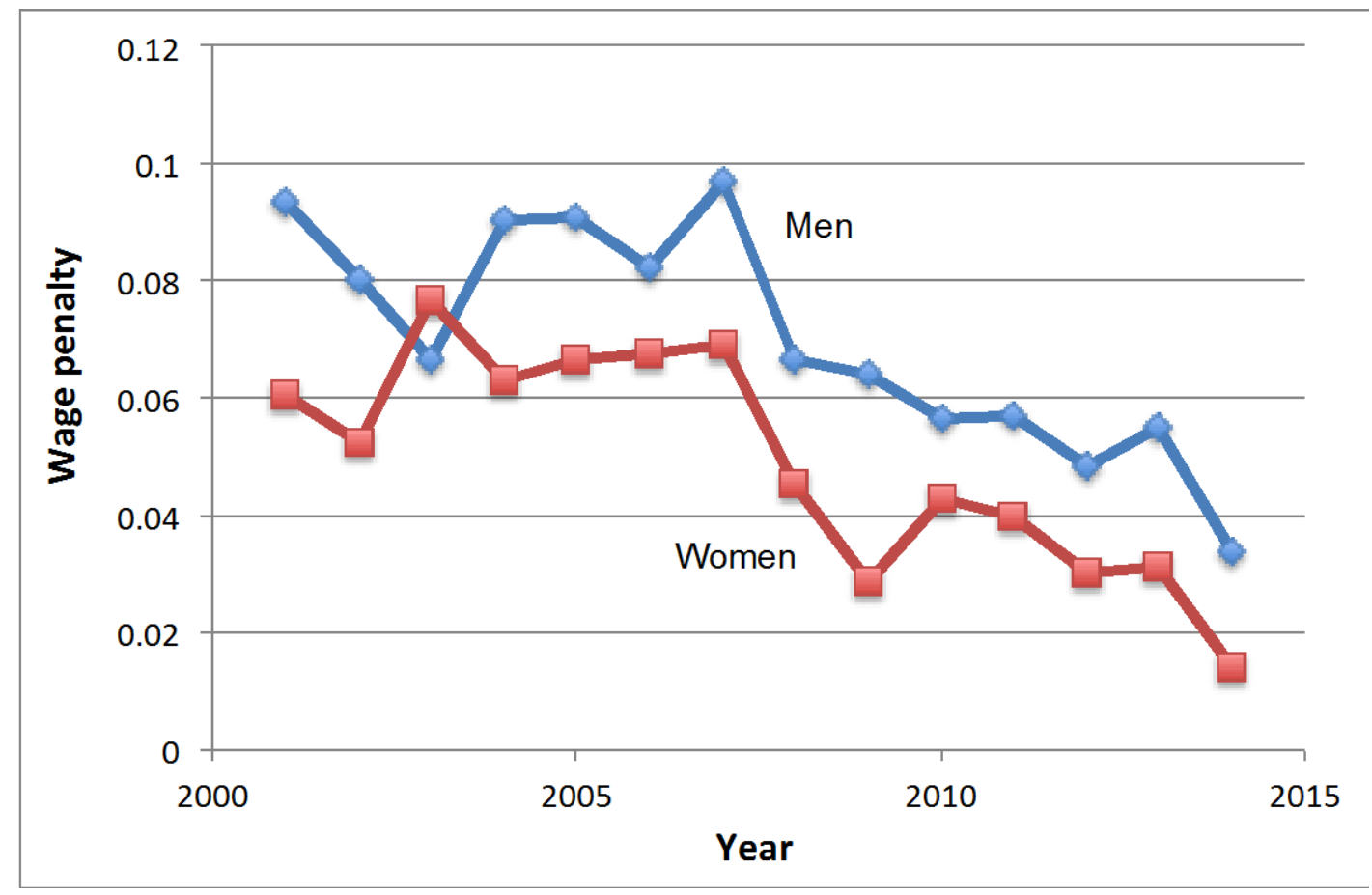

Notes: The wage penalty is the adjusted difference between the log hourly wage of undocumented and legal immigrants calculated in the ACS. It is calculated using the Oaxaca decomposition [see equations (2) and (3) in the text], adjusting for differences in age, educational attainment, state of residence, years-since-migration, and country of birth. The Oaxaca decomposition is conducted separately in each cross-section. 
Figure 7. Wage penalty for undocumented workers in specific cohorts

\section{A. Immigrants in the United States one year}

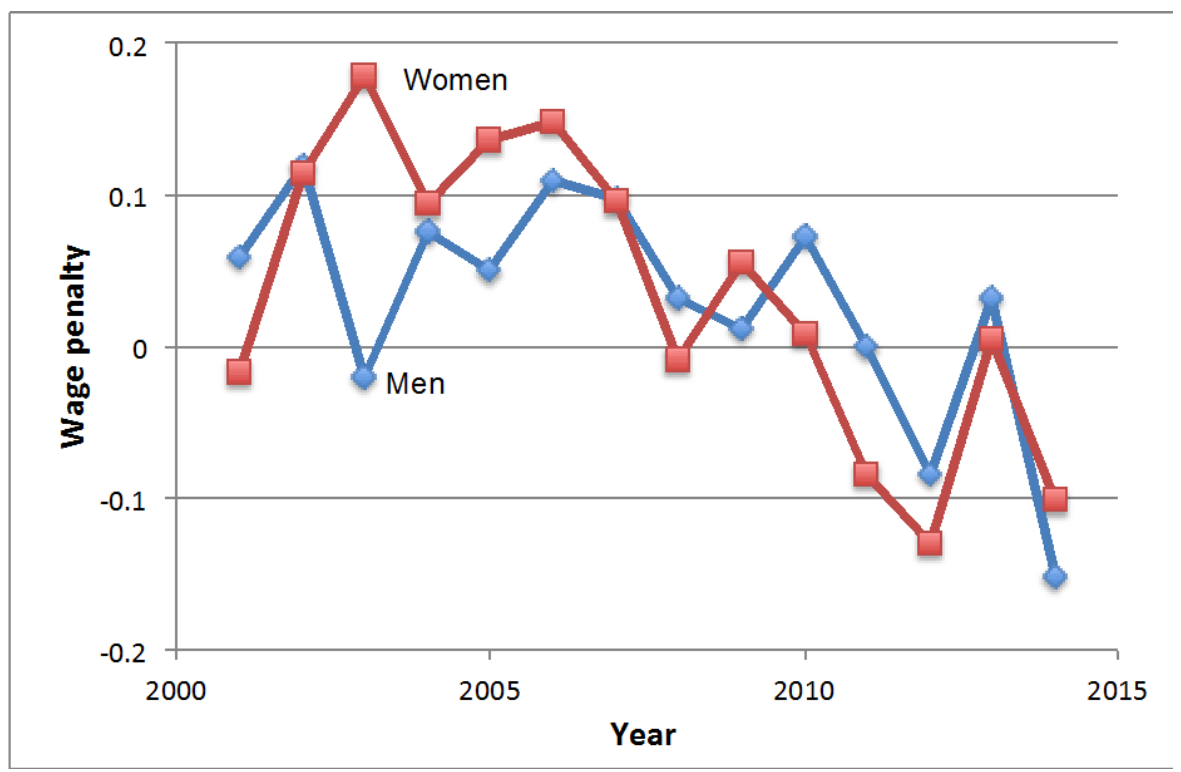

\section{B. Immigrants in the United States 10-20 years}

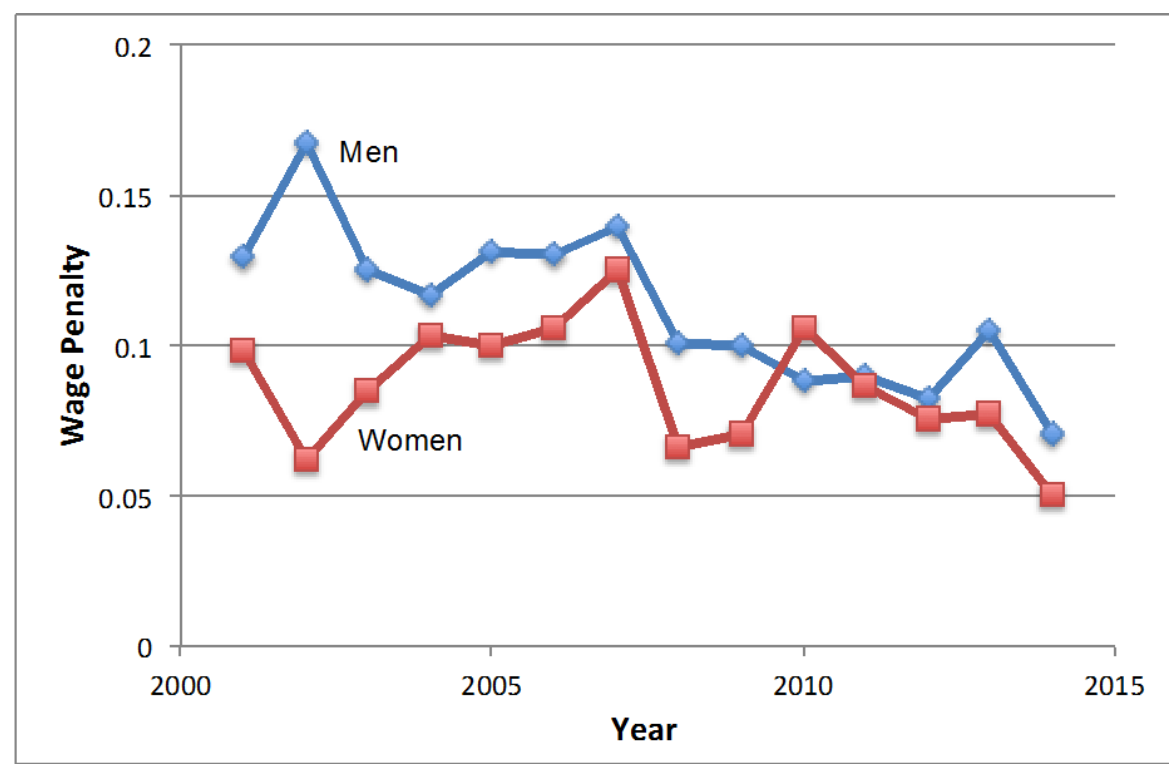

Notes: The wage penalty is the adjusted difference between the log hourly wage of undocumented and legal immigrants calculated in the ACS. It is given by the regression coefficient of a dummy variables indicating whether a person is an undocumented immigrant, the dependent variable is the log hourly wage rate, and the regression is estimated separately in each cross-section using the sample of all foreign-born workers. The regression adjusts for age, educational attainment, state of residence, and country of birth. 
Figure 8. Trend in annual earnings of undocumented men (relative to natives)

\section{A. Adjusted percent earnings gap, men}

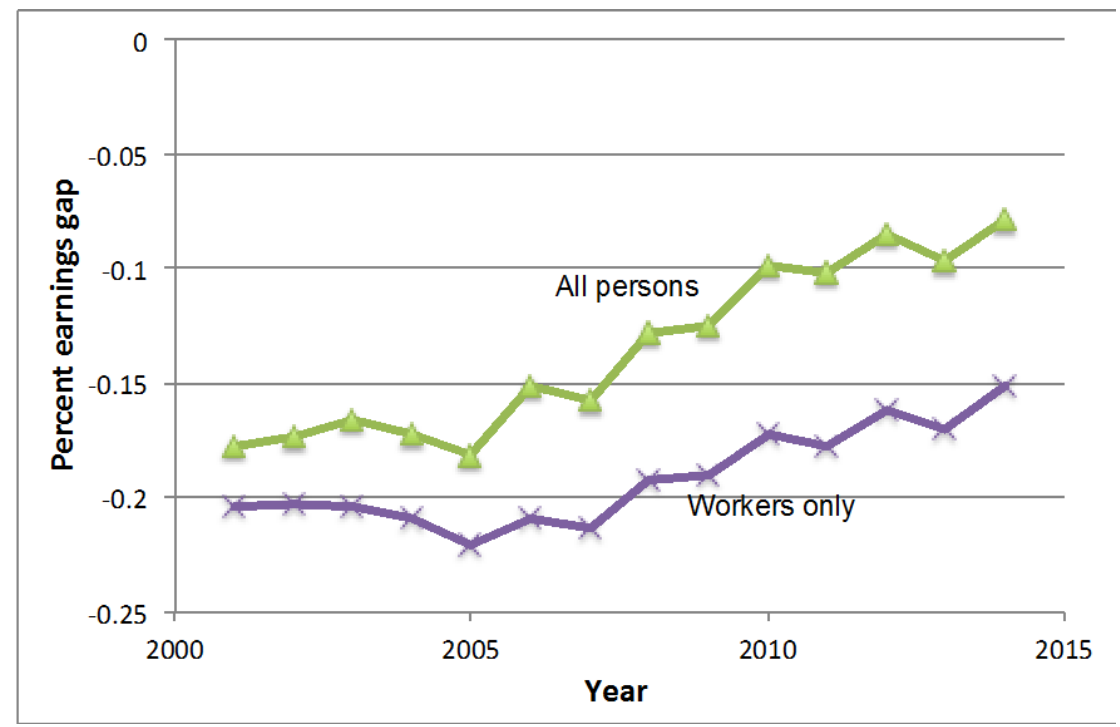

\section{B. Adjusted percent earnings gap, women}

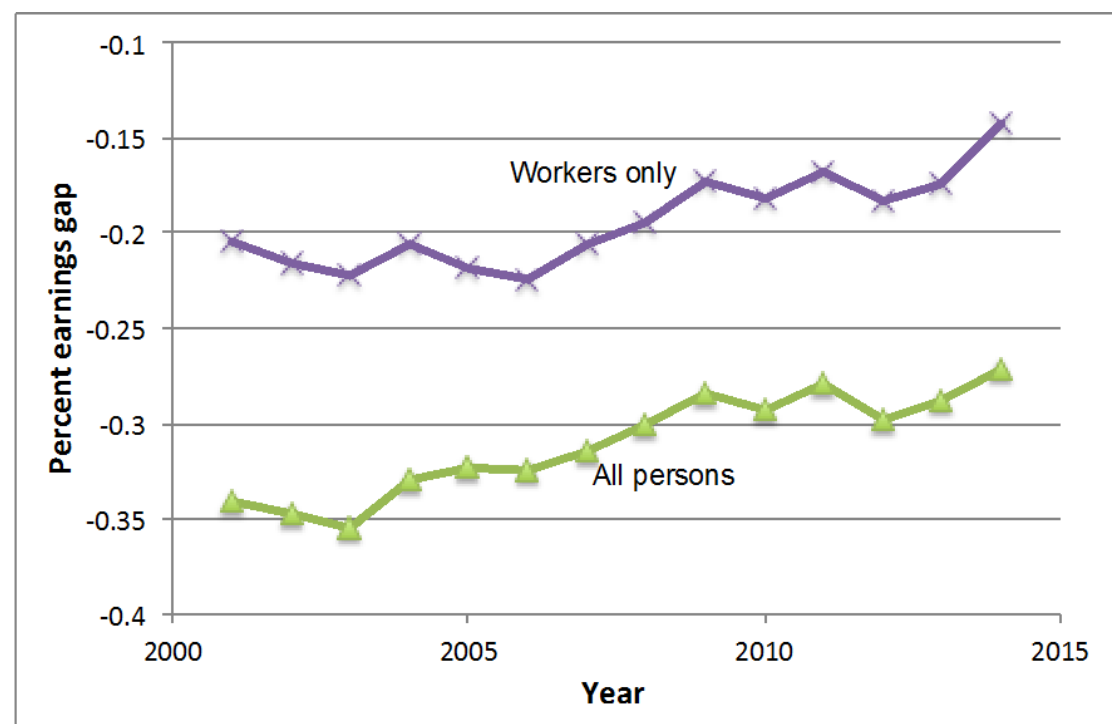

Notes: The figures illustrate the trend in the regression coefficient of dummy variables indicating whether a person is an undocumented immigrant, and the dependent variable in the regression is total annual earnings, relative to average earnings in the cell. The unadjusted coefficient comes from a regression that also controls for whether the person is a legal immigrant, age, educational attainment, and state of residence. The "workers only" regression only includes persons with positive annual earnings; the "all persons" regression includes non-workers and assigns a value of zero to their annual earnings. 


\section{Table 1. Comparison of summary statistics for working men, 2012-2013}

\begin{tabular}{|c|c|c|c|}
\hline \multicolumn{4}{|l|}{ A. Pew CPS files: } \\
\hline Percent of population & 80.6 & 12.5 & 6.9 \\
\hline Average age & 41.5 & 42.4 & 37.3 \\
\hline \multicolumn{4}{|l|}{ Education: } \\
\hline High school dropouts & 5.3 & 20.5 & 45.5 \\
\hline High school graduates & 31.3 & 23.5 & 29.3 \\
\hline Some college & 29.2 & 17.4 & 10.0 \\
\hline College graduates & 34.2 & 38.6 & 15.4 \\
\hline \multicolumn{4}{|l|}{ State of residence: } \\
\hline California & 9.2 & 26.4 & 22.7 \\
\hline New York & 5.4 & 11.2 & 6.7 \\
\hline Texas & 8.2 & 10.2 & 15.0 \\
\hline Log wage gap relative to natives & 0.0 & -0.068 & -0.455 \\
\hline Sample size & 62,247 & 15,059 & 6,851 \\
\hline \multicolumn{4}{|l|}{ B. Reconstructed CPS files: } \\
\hline Percent of population & 81.0 & 11.6 & 7.4 \\
\hline Average age & 41.8 & 43.2 & 37.2 \\
\hline \multicolumn{4}{|l|}{ Education: } \\
\hline High school dropouts & 4.7 & 19.7 & 42.2 \\
\hline High school graduates & 30.4 & 24.4 & 27.8 \\
\hline Some college & 29.1 & 18.7 & 9.2 \\
\hline College graduates & 35.7 & 37.3 & 20.9 \\
\hline \multicolumn{4}{|l|}{ State of residence: } \\
\hline California & 9.2 & 24.9 & 22.4 \\
\hline New York & 5.7 & 11.3 & 7.4 \\
\hline Texas & 8.4 & 10.5 & 15.5 \\
\hline Log wage gap relative to natives & 0.0 & -0.069 & -0.452 \\
\hline Sample size & 54,120 & 8,058 & 4,933 \\
\hline \multicolumn{4}{|l|}{ C. ACS files: } \\
\hline Percent of population & 81.6 & 11.6 & 6.8 \\
\hline Average age & 41.8 & 43.0 & 37.2 \\
\hline \multicolumn{4}{|l|}{ Education: } \\
\hline High school dropouts & 5.8 & 20.5 & 43.7 \\
\hline High school graduates & 31.9 & 26.7 & 27.8 \\
\hline Some college & 31.4 & 20.1 & 10.5 \\
\hline College graduates & 31.0 & 32.8 & 18.0 \\
\hline \multicolumn{4}{|l|}{ State of residence: } \\
\hline California & 9.0 & 25.6 & 24.5 \\
\hline New York & 5.4 & 11.3 & 7.9 \\
\hline Texas & 7.0 & 10.2 & 13.3 \\
\hline Log wage gap relative to natives & 0.0 & -0.042 & -0.404 \\
\hline Sample size & 950,171 & 119,077 & 56,636 \\
\hline
\end{tabular}


Table 2. Log differences in hourly wage rates (relative to natives)

\begin{tabular}{|c|c|c|c|c|}
\hline \multirow{3}{*}{$\begin{array}{l}\text { Regression specification: } \\
\text { A. Pew CPS }\end{array}$} & \multicolumn{2}{|c|}{ Men } & \multicolumn{2}{|c|}{ Women } \\
\hline & \multirow[t]{2}{*}{$\begin{array}{c}\text { Legal } \\
\text { immigrants }\end{array}$} & $\begin{array}{c}\text { Undocumented } \\
\text { immigrants }\end{array}$ & $\begin{array}{c}\text { Legal } \\
\text { immigrants }\end{array}$ & $\begin{array}{c}\text { Undocumented } \\
\text { immigrants }\end{array}$ \\
\hline & & & & \\
\hline \multirow[t]{2}{*}{ 1. No controls } & -.060 & -.455 & -.047 & -.404 \\
\hline & $(.008)$ & $(.010)$ & $(.008)$ & $(.013)$ \\
\hline \multirow[t]{2}{*}{ 2. Adds age } & -.107 & -.417 & -.076 & -.401 \\
\hline & $(.010)$ & $(.010)$ & $(.008)$ & $(.012)$ \\
\hline \multirow[t]{2}{*}{ 3. Adds age, education } & -.073 & -.182 & -.040 & -.154 \\
\hline & $(.007)$ & $(.009)$ & $(.007)$ & $(.012)$ \\
\hline \multirow{2}{*}{$\begin{array}{l}\text { 4. Adds age, education, } \\
\text { geography }\end{array}$} & -.110 & -.211 & -.087 & -.193 \\
\hline & $(.007)$ & $(.010)$ & $(.007)$ & $(.012)$ \\
\hline \multicolumn{5}{|l|}{ B. Reconstructed CPS } \\
\hline \multirow[t]{2}{*}{ 1. No controls } & -.069 & -.452 & -.048 & -.437 \\
\hline & (.009) & $(.011)$ & (.009) & $(.014)$ \\
\hline \multirow[t]{2}{*}{ 2. Adds age } & -.116 & -.404 & -.079 & -.432 \\
\hline & (.009) & $(.010)$ & $(.008)$ & $(.014)$ \\
\hline \multirow[t]{2}{*}{ 3. Adds age, education } & -.067 & -.194 & -.041 & -.187 \\
\hline & $(.008)$ & $(.010)$ & $(.008)$ & $(.013)$ \\
\hline \multirow{2}{*}{$\begin{array}{l}\text { 4. Adds age, education, } \\
\text { geography }\end{array}$} & -.100 & -.224 & -.085 & -.228 \\
\hline & $(.008)$ & $(.010)$ & $(.008)$ & $(.013)$ \\
\hline \multicolumn{5}{|l|}{ C. ACS } \\
\hline \multirow[t]{2}{*}{ 1. No controls } & -.042 & -.404 & -.017 & -.396 \\
\hline & $(.002)$ & $(.003)$ & $(.002)$ & $(.004)$ \\
\hline \multirow[t]{2}{*}{ 2. Adds age } & -.093 & -.350 & -.051 & -.381 \\
\hline & $(.002)$ & $(.003)$ & $(.002)$ & $(.003)$ \\
\hline \multirow[t]{2}{*}{ 3. Adds age, education } & -.048 & -.150 & -.010 & -.143 \\
\hline & $(.002)$ & $(.003)$ & $(.002)$ & $(.003)$ \\
\hline \multirow{2}{*}{$\begin{array}{l}\text { 4. Adds age, education, } \\
\text { geography }\end{array}$} & -.091 & -.188 & -.074 & -.199 \\
\hline & $(.002)$ & $(.003)$ & $(.002)$ & $(.003)$ \\
\hline
\end{tabular}

Notes: Standard errors are reported in parentheses. The dependent variable gives a worker's log hourly wage rate. The regressions control for age by including a vector of fixed effects indicating the worker's age in five-year bands (20-24, 25-29, and so on). The regressions control for educational attainment by including a vector of fixed effects indicating if the person is a high school dropout, a high school graduate, has some college, or is a college graduate. The controls for geography include a vector of fixed effects indicating the person's state of residence. All regressions also include a dummy variable indicating if the observation was drawn from the 2012 cross-section. The male (female) regressions estimated in the Pew files have 84,151 (76.034) observations. The male (female) regressions estimated in the reconstructed files have $67,111(64,775)$ observations. The male (female) regressions estimated in the reconstructed files have 1,125,884 $(1,068,609)$ observations. 
Table 3. Returns to schooling, 2012-2013

A. Men

1. Pew CPS files

2. Reconstructed CPS files

\begin{tabular}{ccc} 
Natives & $\begin{array}{c}\text { Legal } \\
\text { Immigrants }\end{array}$ & $\begin{array}{c}\text { Undocumen } \\
\text { immigran }\end{array}$ \\
\hline .115 & .092 & .074 \\
$(.001)$ & $(.002)$ & $(.002)$ \\
.117 & .092 & .065 \\
$(.001)$ & $(.001)$ & $(.002)$ \\
.112 & .079 & .061 \\
$(.000)$ & $(.001)$ & $(.001)$
\end{tabular}

B. Women

1. Pew CPS files

.125

.098

.065

$(.001)$

$(.002)$

$(.003)$

2. Reconstructed CPS files

.126

.095

.065

$(.001)$

$(.002)$

$(.003)$

3. ACS

.113

.085

.054

$(.000)$

$(.001)$

$(.001)$

Notes: Standard errors are reported in parentheses. The dependent variable is the worker's log hourly wage rate. The regressors also include age fixed effects and state of residence fixed effects. 


\section{Table 4. Wage penalty to undocumented status in 2012-2013 cross-section}

Sample

A. Men

1. Pew CPS

2. Reconstructed CPS

3. ACS

\begin{tabular}{cccccc}
\multicolumn{7}{c}{ Specification } \\
\hline$(1)$ & $(2)$ & $(3)$ & $(4)$ & $(5)$ & $(6)$ \\
\hline 387 & .343 & .321 & .076 & .072 & -- \\
$(.011)$ & $(.011)$ & $(.011)$ & $(.011)$ & $(.011)$ & \\
.383 & .304 & .277 & .084 & .087 & -- \\
$(.013)$ & $(.014)$ & $(.015)$ & $(.014)$ & $(.014)$ & \\
.361 & .271 & .229 & .067 & .065 & .050 \\
$(.004)$ & $(.004)$ & $(.004)$ & $(.004)$ & $(.004)$ & $(.004)$
\end{tabular}

B. Women

1. Pew CPS

2. Reconstructed CPS

3. ACS

\section{.358}

(.012)

.389

(.016)

.379

(.004)

\section{.342}

(.013)

.371

(.016)

.340

(.005)
.311
$(.013)$
.337
$(.017)$

.283

(.005)
.082

(.012)

.107

(.016)

.071

(.004)

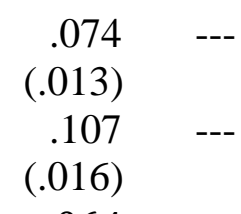

.064

(.004)
.033

(.005)

\section{Controls for:}

Age

Years-since-migration

$\begin{array}{ll}\text { No } & \text { Yes } \\ \text { No } & \text { No } \\ \text { No } & \text { No } \\ \text { No } & \text { No } \\ \text { No } & \text { No }\end{array}$

Yes

Yes

Yes

Yes

Yes

Yes

Yes

No Yes

Yes

Yes

Education

State of residence

Country of birth

No

No

Yes

Yes

No

No

Yes

Yes

Notes: The dependent variable gives a worker's log hourly wage rate. The statistics reported in the table are the results from an Oaxaca decomposition [see equations (2) and (3) in the text] that estimates the wage gap between observationally equivalent undocumented and legal immigrants. The years-since-migration variable is introduced as a fourth order polynomial; the age, education, and state of residence variables are introduced as vectors of fixed effects. 


\section{Table 5. Impact of state-level E-Verify mandate on wage penalty}

\section{Sample:}

\begin{tabular}{cc}
\hline Men & Wome \\
\hline & \\
.019 & .012 \\
$(.008)$ & $(.013)$ \\
.144 & .115 \\
$(.066)$ & $(.083)$ \\
-.012 & .015 \\
$(.011)$ & $(.013)$
\end{tabular}

Reconstructed CPS, 2002-2015 surveys

All immigrants

Fixed effects included:

Year, education, age, state, and country of birth Immigration status-year and immigration status-state

State-year

$\begin{array}{ll}\text { Yes } & \text { Yes } \\ \text { Yes } & \text { Yes } \\ \text { Yes } & \text { Yes }\end{array}$

Notes: Standard errors are reported in parentheses and are clustered at the state level. The statistics reported in the table are the coefficients of an interaction between a dummy variable indicating whether a worker is a legal immigrant and whether that worker lived in a state-year cell that mandated all employers to use E-Verify to authenticate the employment eligibility of job applicants. The regressions are estimated in the sample of foreignborn workers and pool all the indicated cross-sections. All regressions include the variable indicating whether the state-year cell mandates the use of E-Verify and a fourth order polynomial giving the number of years since migration. The number of observations for the ACS regressions are 982,147 for men, and 789,816 for women. The number of observations for the regressions using the sample of new immigrant men (women) in the ACS is 33,928 $(19,385)$; the number of observations for the regressions using the sample of older immigrant men (women) in the ACS is 719,045 $(609,842)$. The number of observations for the CPS regressions are 89,669 and 67,698 for men and women, respectively. 


\section{Table 6. Interaction between relative earnings and labor supply (annual earnings in thousands of dollars)}

\begin{tabular}{|c|c|}
\hline All persons & Sample of workers \\
\hline (2) & (2) \\
\hline
\end{tabular}

A. CPS Pew, men Legal

Undocumented

B. CPS Pew, women

Legal

Undocumented

C. ACS, men

Legal

Undocumented

D. ACS, women

Legal

Undocumented

Controls for:

Educational attainment, age, and state of residence
$-5.38$

$-4.31$

(.76)

$-8.60$

(.65)

$-5.50$

$-26.42$

(1.02)

(.89)

(.88)

$-5.50$

(.37)

$-.92$

(.51)

(.37)

$-7.08$

$-15.28$

(.56)

(.83)

(.75)

$-10.87$

(1.03)

$-14.59$

(.57)

$-2.34$

$-2.13$

$-6.13$

(.15)

$-3.62$

(.51)

$-6.59$

(.82)

(.13)
(.14)

(.17)

$-4.14$

$-23.07$

(.18)

(.22)

$-3.32$

(.09)

.35

(.12)

$-7.99$

$-14.60$

(.13)

(.19)

Yes

No

$-9.86$

(.21)

$-2.83$

(.11)

$-6.88$

(.18)

No

Yes

Notes: Standard errors are reported in parentheses. The regressions use the pooled sample of the 2012-2013 CPS Pew files, or the pooled sample of the 2011-2012 ACS. The dependent variable gives a worker's annual earnings, which equals zero if the person did not work at all during the year. All regressions include a dummy variable indicating if the observation was drawn from the 2012 cross-section. The male (female) regressions estimated in the Pew files have 114,614 $(121,608)$ observations in the "all-persons" sample, and 91,444 $(82,165)$ observations in the sample of workers. The male (female) regressions estimated in the ACS have 1,611,907 $(1,625,742)$ observations in the "all-persons" sample, and 1,202.031 $(1,104,444)$ observations in the sample of workers. 